Annals of Tropical Research 30[2]: 44-55(2008)

(c) VSU, Leyte, Philippines

\title{
Growing tropical tree planting stock in root trainers: Cell volume, seedling density and growing media
}

\author{
Sanjay Singh ${ }^{1}$, N. P. S. Nain ${ }^{2}$ and S. P. Tripathi ${ }^{2}$ \\ ${ }^{1}$ Botany, Silviculture and NWFP Division, Institute of Forest Productivity, \\ Aranyodaya, NH-23, Lalgutwa, Ranchi- 835303, India; \\ ${ }^{2}$ Tropical Forest Research Institute, P. O. - RFRC, Jabalpur- 482021
}

\begin{abstract}
The influence of root trainer cell volume and seedling density, and composition of growing media was examined in relation to morphological, biomass and seedling quality parameters of four-month old planting stock of three tropical broadleaved tree species viz., Acacia catechu, Azadiractha indica and Pongamia pinnata. The study revealed that a cell volume of $90 \mathrm{~cm}^{3}$ was not sufficient for proper seedling growth of $A$. catech $u$ and $A$. indica. However, clear-cut superiority of $300 \mathrm{~cm}^{3}$ cell volume was evident only in the case of $A$. indica. It appeared that root trainer pots of $150 \mathrm{~cm}^{3}$ cell volume were suitable for growth of planting stock of $A$. catechu and $P$. pinnata and $300 \mathrm{~cm}^{3}$ cell volume for $A$. indica. Significant differences in the growth of planting stocks were observed among growing media treatments. Overall the tree species exhibited fast growth and high biomass as well as favorable seeding quality in growing media containing $80 \%$ compost with either sand (A. catechu and A. indica) or soil (P. pinnata) than the other treatments having $50 \%, 60 \%$ or $100 \%$ compost.
\end{abstract}

Keywords: biomass, height and root collar diameter, hiko pots, seedling quality

Correspondence: S. Singh. Address: Botany, Silviculture and NWFP Division, Institute of Forest Productivity, Aranyodaya, NH-23, Lalgutwa, Ranchi- 835303. E-mail: sanjaysingh@lycos.com. Phone: 91-651-2548505. Fax: 91-651-2241457

Dol: $10.32945 /$ atr3024.2008 


\section{INTRODUCTION}

Most tropical forest nurseries have predominantly used polythene bags for raising planting stock despite the inherent disadvantages of these containers. Research shows that use of these containers result to poor root development and subsequent poor establishment of grown stock in the field (Burden, 1979; Sharma, 1987; Venator et al. 1985). However, the popularity of polythene bags in tropical nurseries is more of a function of the apparent hardiness of the seedlings being grown than actual beneficial attributes (Wilson, 1986). In recent years, the use of root trainer pots has increased but species-specific technical packages with experimentally proven prescriptions about cell volume, seedling density and growing media have not been developed for most of the important tropical broadleaved forestry species. Hence, this study was conducted to standardize root-trainer stock production prescriptions for three important tropical broadleaved trees including, Acacia catechu, Azadiractha indica and Pongamia pinnata by investigating the influence of cell volume, seedling density and the composition of growing media.

\section{MATERIALS AND METHODS}

Two experiments involving Acacia catechu $\left(\mathrm{S}_{1}\right)$, Azadiractha indica $\left(\mathrm{S}_{2}\right)$ and Pongamia pinnata $\left(\mathrm{S}_{3}\right)$ were carried out during the months of March to June (the usual planting stock growing period in India for planting during the monsoon rains in July-August) at the Model Research Nursery, Tropical Forest Research Institute, Jabalpur (23 $\left.10^{\prime} \mathrm{N}, 79^{\circ} 59^{\prime} \mathrm{E}\right)$. Three different types of root trainers (hiko pots) with varying cell volume and seedling density were used in the first experiment (Table 1). They were filled with a uniform growing medium of compost and sand in a ratio of $4: 1$ based on earlier study conducted in the same nursery on appropriate growing medium for root trainer seedling production of some tropical trees (Singh et al. 2004). In the second experiment five growing media comprised of compost in varying proportions with soil and/or sand were evaluated for seedling growth in root trainer pots (Table 2). In both of these experiments the experimental design was a randomized block design replicated four times with each replication having 40 seedlings. Pregerminated seeds were placed in root trainer cells. The seedlings were watered regularly (twice a day). 
Table 1. Cell volume and seedling density of root trainers (Hiko pots) in experiment 1.

\begin{tabular}{lcc}
\hline Treatments & $\begin{array}{l}\text { Cell volume } \\
\left(\mathrm{cm}^{3}\right)\end{array}$ & $\begin{array}{l}\text { Seedling density } \\
\left(\text { seedlings } \mathrm{m}^{-2}\right)\end{array}$ \\
\hline $\mathrm{T}_{1}\left(90 \mathrm{~cm}^{3} ; 575\right.$ seedlings $\left.\mathrm{m}^{-2}\right)$ & 90 & 575 \\
$\mathrm{~T}_{2}\left(150 \mathrm{~cm}^{3} ; 225\right.$ seedlings $\left.\mathrm{m}^{-2}\right)$ & 150 & 225 \\
$\mathrm{~T}_{3}\left(300 \mathrm{~cm}^{3} ; 144\right.$ seedlings $\left.\mathrm{m}^{-2}\right)$ & 300 & 144 \\
\hline
\end{tabular}

Table 2. Composition of growing media treatments in experiment 2.

\begin{tabular}{lccc}
\hline Treatments & \multicolumn{3}{c}{ Components (\%) } \\
\cline { 2 - 4 } & Compost & Nursery Soil & River Sand \\
\hline $\mathrm{T}_{1}$ & 50 & 25 & 25 \\
$\mathrm{~T}_{2}$ & 60 & 20 & 20 \\
$\mathrm{~T}_{3}$ & 80 & 0 & 20 \\
$\mathrm{~T}_{4}$ & 80 & 20 & 0 \\
$\mathrm{~T}_{5}$ & 100 & 0 & 0 \\
\hline
\end{tabular}

Seedling height and root collar diameter were measured during the first week of July by removing all the seedlings of each replicate from the root trainer pots. However, for the study of root system and biomass parameters, ten seedlings per replication were randomly selected. The root plugs were gently washed with water to remove particles of growing medium which had adhered to them. After that shoot and root components were separated and oven dried at $70^{\circ} \mathrm{C}$ to record biomass (weight in $\mathrm{g} /$ seedling). The data on seedling height, root collar diameter and biomass (shoot, root and total) were statistically analyzed employing analysis of variance (ANOVA), ' $F$-test to ascertain significance at $p \leq 0.05$ and least significant difference $\left(\operatorname{LSD}_{0.05}\right)$ values to separate means in different statistical groups (Gomez and Gomez, 1984) using 'SX' (Statix PC DOS version, 1985, 1987; NH Analytical software). Based on the data recorded, secondary parameters were calculated to assess the overall seedling quality. These included a sturdiness quotient (calculated as the height in $\mathrm{cm}$ /diameter in $\mathrm{mm}$ ), a volume index [(Diameter in $\mathrm{mm})^{2} \mathrm{x}$ height in $\mathrm{cm}$ ] and a Dickson quality index (total seedling dry weight in $\mathrm{g} /$ sturdiness quotient + shoot/root dry weight ratio; after Dickson et al. 1960). 


\section{RESULTS}

Influence of container volume and seedling density on seedling growth

Significantly superior $(p \leq 0.05)$ morphological features as well as shoot and total biomass production were recorded in the seedlings raised in 300 $\mathrm{cm}^{3}$ hiko pots with a density of 144 seedlings $\mathrm{m}^{-2}\left(\mathrm{~T}_{3}\right)$ in $A$. catech $u$ and $A$. indica (Table 3). All the species exhibited significantly different $(p \leq 0.05)$ root biomass in various treatments. In A. catechu and P. pinnata $\mathrm{T}_{2}(150$ $\mathrm{cm}^{3} ; 225$ seedlings $\mathrm{m}^{-2}$ ) and $\mathrm{T}_{3}$ recorded statistically similar but higher root biomass production than $90 \mathrm{~cm}^{3}$ root trainer pots. Container volume of 300 $\mathrm{cm}^{3}$ was proved the best for root biomass in A. indica.

Among quality parameters, the best sturdiness quotient was revealed in $300 \mathrm{~cm}^{3}$ root trainer pots (144 seedlings $\left.\mathrm{m}^{-2}\right)$ for $A$. indica and $P$. pinnata and $\mathrm{T}_{1}\left(90 \mathrm{~cm}^{3} ; 575\right.$ seedlings $\left.\mathrm{m}^{-2}\right)$ for $A$. catech $u$ while superior root shoot ratio was recorded in $\mathrm{T}_{3}$ in $A$. indica (Table 4). The remaining two species leaving $P$. pinnata exhibited maximum values of volume and Dickson quality indices in $\mathrm{T}_{3}$. In $P$. pinnata the highest value of Dickson quality index was recorded in $150 \mathrm{~cm}^{3}$ root trainer pots.

\section{Influence of growth media on seedling growth}

Among the morphological parameters, height, root collar diameter, shoot biomass, root biomass and total biomass, the growing media treatments significantly influenced $(p \leq 0.05)$ seedling height in $A$. catech $u$ (the best 25 $\mathrm{cm}$ in $\mathrm{T}_{3}$ having $80 \%$ compost with $20 \%$ sand) and root collar diameter in $A$. indica and P. pinnata, with $\mathrm{T}_{3}(5.08 \mathrm{~mm})$ and $\mathrm{T}_{4}$ i. e. $80 \%$ compost with $20 \%$ soil $(5.34 \mathrm{~mm})$ respectively being the best treatments. A. indica also recorded statistically superior $(p \leq 0.05)$ shoot biomass and total biomass production in $\mathrm{T}_{3}$ along with $\mathrm{T}_{5}(100 \%$ compost $)$ than other growing media (Table 5).

Three out of four quality parameters, i. e. the sturdiness quotient, volume and the Dickson Quality index showed the superiority of $\mathrm{T}_{3}$ over other treatments in case of $A$. indica. The values for Dickson quality index were almost similar for all treatments in $A$. catechu and P. pinnata but volume 
48

Singh et al

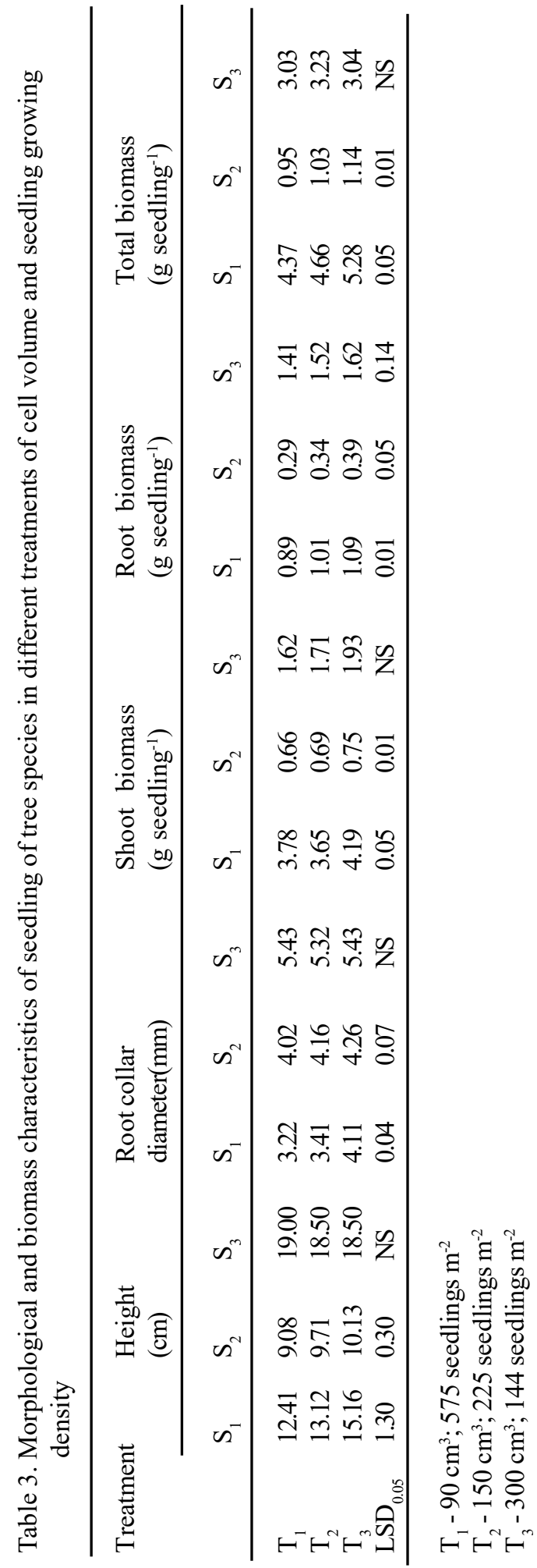




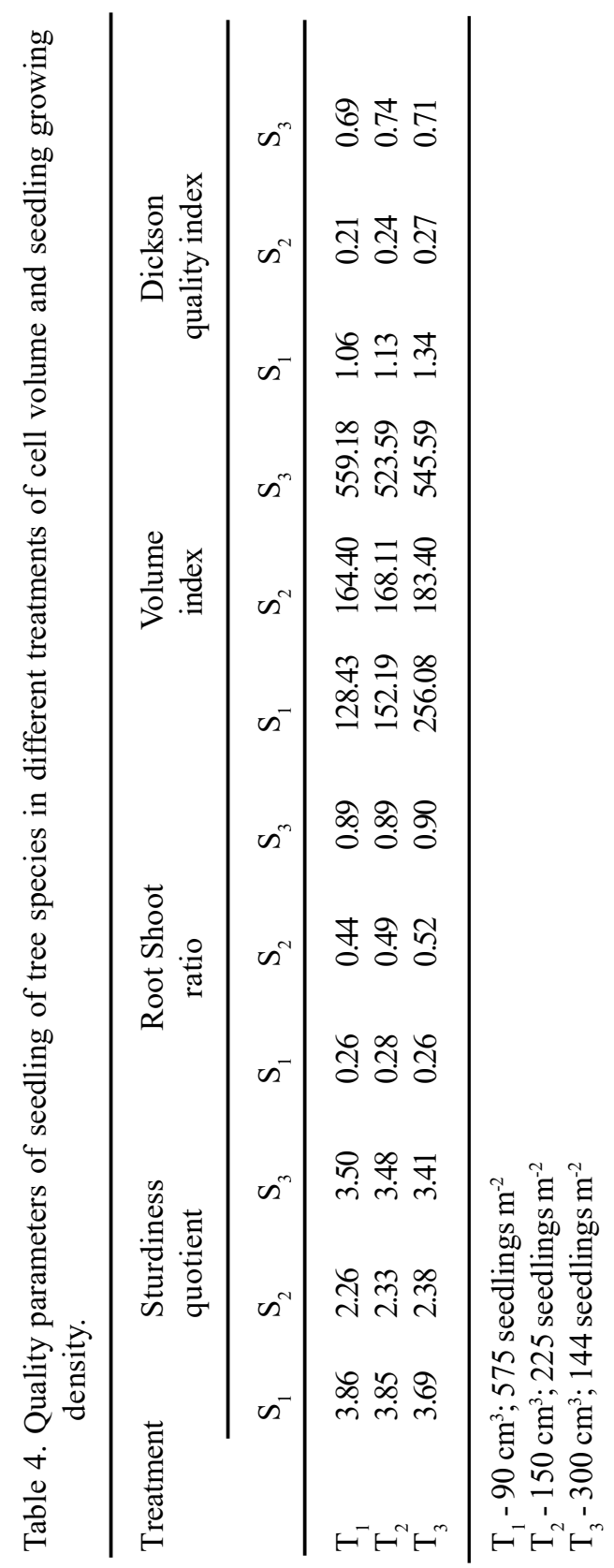




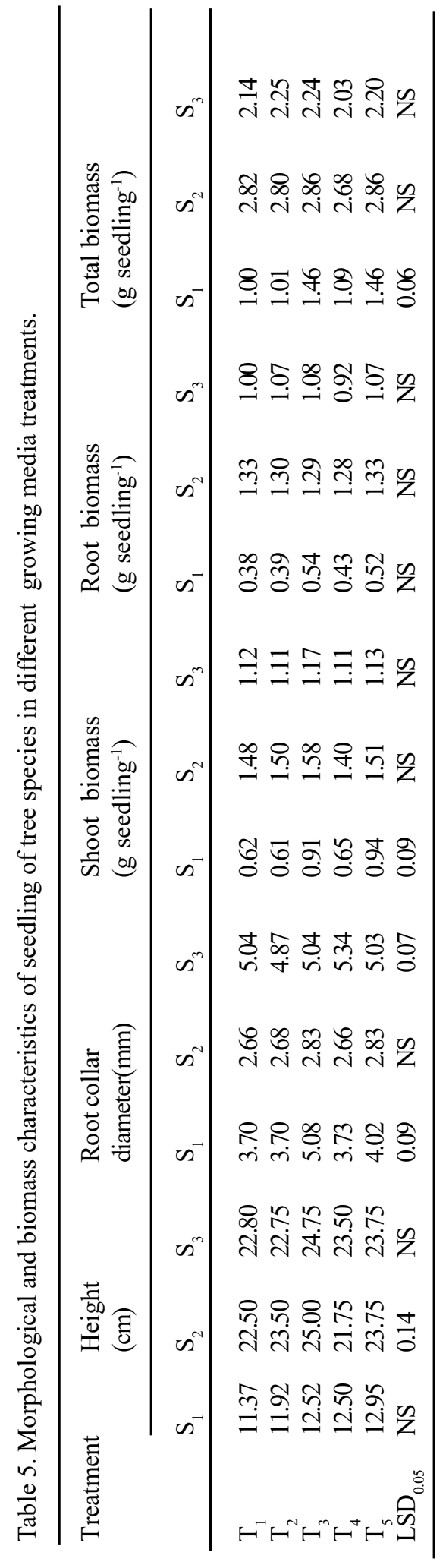




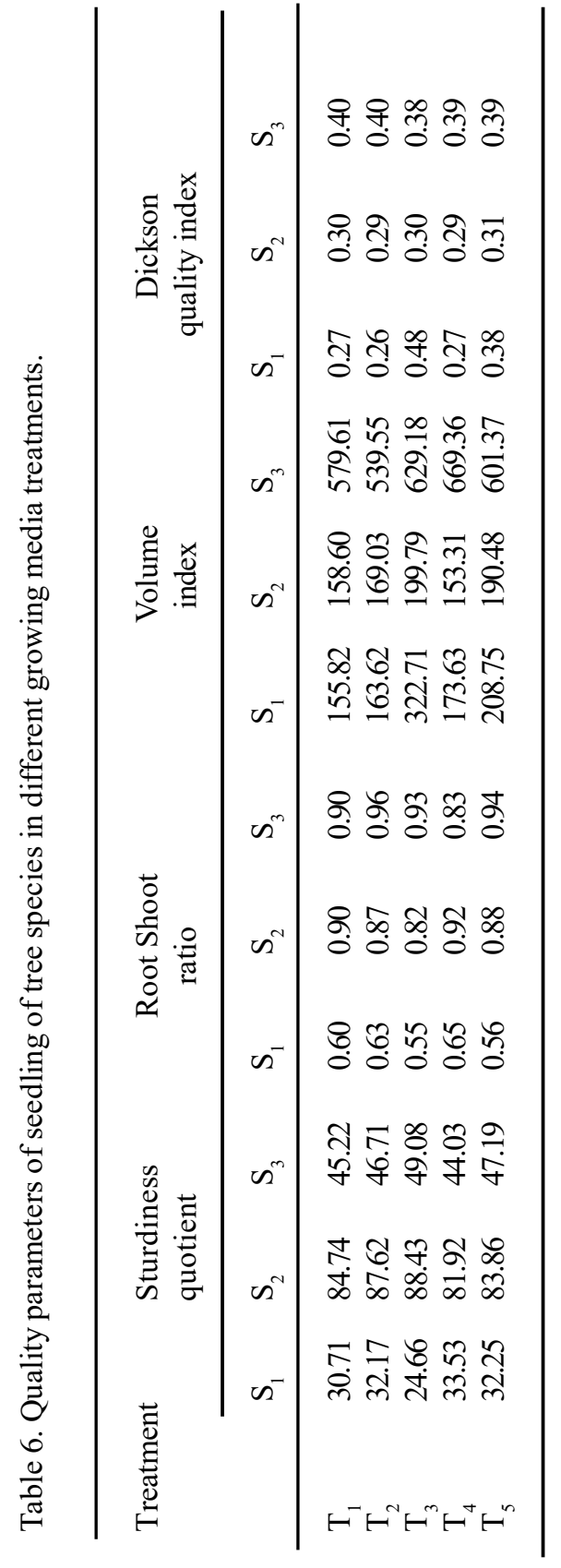


index indicated $\mathrm{T}_{3}(322.71)$ being the best for the former and $\mathrm{T}_{4}(669.36)$ for the latter. $\mathrm{T}_{4}$ treatment also had the best sturdiness quotient (44.03) in $P$. pinnata (Table 6).

\section{DISCUSSION}

Influence of container volume and seedling density on seedling growth

Optimum container size varies according to species, desired size of seedlings, growing density and medium, environmental conditions and length of growing season (Landis, 1990). Increase in container volume (and thus rooting volume) generally results in enhanced rate of growth and increased seedling size (Carlson and Endean, 1976; Alm et al. 1982; Liegel and Venator, 1987). However, the benefits of large containers should be weighed with the higher cost per seedling produced. Ideally, the smallest container which gives satisfactory survival and growth for a given species should be used (Evans, 1982).

Results of this investigation indicated that a cell volume of $90 \mathrm{~cm}^{3}$ is not sufficient for proper growth of seedlings of the tropical broadleaved tree species under study viz., A. catechu, A. indica and P. pinnata. However, the superiority of root trainer pots of $300 \mathrm{~cm}^{3}$ volume was evident only in the case of $A$. indica for all morphological, biomass and quality parameters. In $P$. pinnata, the effect of cell volume was observed only for root biomass with both 150 and $300 \mathrm{~cm}^{3}$ cell volume having statistically similar results. The improvement in quality of seedlings from $150 \mathrm{~cm}^{3}$ to $300 \mathrm{~cm}^{3}$ root trainer pots was not substantial for $A$. indica as evident from the all four quality parameter values calculated in this study. For example, the increase in volume index in this species is only $9 \%$ compared to $68 \%$ increment in $A$. catechu. Overall, it may be ascertained that except for $A$. indica which demands a cell volume of $300 \mathrm{~cm}^{3}$, the other two species can be grown in root trainers of cell volume of $150 \mathrm{~cm}^{3}$ without comprising seedling quality. Smaller cells with lesser seedling space will also help economize on the cost of seedling production in these 
species due to low inputs and more seedlings compared to larger trays.

Tree seedlings also require a certain minimum amount of growing space, which varies with species and age (Simpson, 1991, 1994; Singh et al. 2005). In general tropical broadleaved species tend to require large containers with their concomitant lower growing density than conifers and eucalypts as their large leaves intercept more water and nutrients and generate more shade. Therefore, spacing of seedlings in root trainer pots is crucial for shoot development, seedling growth and stem form. This seems a plausible cause of superior morphology, shoot and root biomass and quality production of broadleaved species under investigation in larger volume cells with more espacement and thus lower density. In conclusion, root trainers of $150 \mathrm{~cm}^{3}$ cell volume (providing 225 seedlings $\mathrm{m}^{-2}$ ) are suitable for growing quality planting stock of $A$. catechu and $P$. Pinnata and $300 \mathrm{~cm}^{3}$ ( providing 144 seedlings $\mathrm{m}^{-2}$ ) for $A$. indica.

\section{Growing media}

Compared to field-grown plants, seedlings raised in containers have access to a very limited amount of growing medium (Swanson, 1989). They have unique functional requirements which must be supplied by the growing medium (Mastalerz, 1977). Milk et al.(1989) emphasized that plants growing in small containers often experience growth problems due to poor aeration or low water holding capacity of the growing medium. Therefore, the textural properties of growing medium must be carefully chosen and blended to produce right mixture of porosity that will persist over the growing cycle (Landis, 1990).

Incorporation of organic material such as compost prepared in the nurseries from locally abundant weeds and leaf litter can considerably improve aeration and water holding capacity of the growing medium at minimal cost. The first scientifically standardized horticultural growing medium in England during 1930s contained a loam-based compost (Bunt, 1988). The media containing compost from agricultural wastes have been reported to enhance height, stem diameter and biomass of ornamentals (Chen et al. 1988). In some of the experiments, compost-based media have outperformed peat-based media (Lamrana et al. 
1991; Fitzpatrick, 1994; Pronk et al. 1995). However, species-specific variations in root architecture and nutritional requirements deserve to be taken into account before deciding the proportion of compost in a growing medium. In the present investigation, all the tree species exhibited better growth, biomass as well as seedling quality in growing media containing $80 \%$ compost with either sand or soil. This is in contrast to traditional prescriptions of growing media being followed by Indian forest nurseries having compost (or farm yard manure) not more than $25 \%$ invariably with both forest soil and sand either $25 \%$ or $50 \%$. However, we recommend growing media having $80 \%$ compost which seemed to have not only ensured required nutritional input during the growing period but also enhanced porosity and water holding capacity of the medium for raising planting stock of $A$. catechu, $A$. indica and $P$. pinnata in root trainers.

\section{LITERATURE CITED}

ALM, A., D. OLSE, and M. LEAKEY. 1982. Comparison after planting jack pine grown for varying time periods in different container systems. Minn. For. Res. Notes 279, University of Minnesota.

BRAGG, N. C., and B. J. CHAMBERS. 1988. Interpretation and advisory applications of air-filled porosity (AFP) measurements. Acta Horticultuare 221: 35-44.

BUNT, A. C. 1988. Media and Mixes for Container-Grown Plants. Unwin Hymen Boston.

BURDEN, A. N. (1979) Juvenile instability in planted pines. Irish Forestry 36:36-47.

CARLSON, L. W.and F. ENDEAN. 1976. The effect of rooting volume and container configuration on the early growth of white spruce seedlings. Canadian Journal of Forest Research 6: 221-224.

CHEN, Y., Y. INBAR, and Y. HADAR. 1988. Composted agricultural wastes as potting media for ornamental plants. Soil Science 145: 298-303.

DICKSON, A., A. L. LEAF, and J. F. HOSNER. 1960. Quality appraisal of white spruce and white pine seedling stock in nurseries. Forestry Chronicle 36:10-13.

EVANS, J. 1982. Plantation Forestry in the Tropics. Clerendon Press Oxford.

FITZPATRICK, G. 1994. Evaluation of potting mixes derived from the urban waste products. Prov. Florida State Hort. Science 94: 45-97.

GOMEZ, K. A. and A. A.GOMEZ . 1984. Statistical Procedures for Agricultural Research. Wiley, Singapore. 
LAMARANA, D., M. CASTLELNUOVO, and G. ANGELO . 1991. Compost-based media as alternative to peat on ten pot ornamentals. Acta Horticulturae 294: 125-129.

LANDIS, T. D. 1990. The Container Tree Nursery Manual. Vol. II: Containers and Growing Media. Forest Service USDA Handbook 674.

LIEGEL, L. H.and C. R.VENATOR . 1987. A Technical Guide for Forest Nursery Management in the Caribbean and Latin America. Gen. Tech. Rep. S0-67 USDA Forest Service New Orleans.

MASTALERZ, J. W. 1977. The Greenhouse Environment. John Willey and Sons New York.

MILK, R. R., W. C. FONTENO and R. A. CARLSON. 1989. Hydrology of horticultural substances: III. Predicting air and water content of limited-volume plus cells. Journal of American Society of Horticultural Science 14: 57-63.

PRONK, A. A., P. ADAMS , A. P. HIDDINGS, J.A. KIP, C. SONNVELD and C. KREIJ. 1995. Composted fruit, vegetable and garden waste as a substitute for peat in container grown nursery stock. Acta Horticulturae 401: 473-480.

SANJAY, SINGH, A. S. BHANDARI, S. K. JHARIA, K. K. KUNJAM and P. K. SHUKLA. 2004. Suitability of compost-based growing media for raising planting stock of tropical trees in root trainers. My Forest 40: 69-76.

SANJAY SINGH, A. S. BHANDARI, S. K. JHARIA, K. K. KUNJAM and P. K. SHUKLA. 2005. Influence of root trainer cell volume and seedling density on planting stock of tropical broadleaved trees. Journal of Tropical Forestry 21: 207-212.

SHARMA, R. D. 1987. Some observations on coiling of roots in nursery raised plants. Journal of Tropical Forestry 3:207-212.

SIMPSON, D. D. 1991. Crowding density and container volume affect nursery and field growth of interior spruce seedlings. N. J. Appl. For. 8: 160-165.

SIMPSON, D. D. 1994. Nursery growing density and container volume affect nursery and field growth of douglas fir and lodgepole pine seedlings. Proc. Forest and Conservation Nursery Associations. July 11-14, 1994 Williamburg.

SWANSON, B. R. 1989. Critical physical properties of container media. American Nurseryman 169: 59-63.

VENATOR, C. R., L. H. LIEGEL and J. P. BARNETT. 1985. Bareroot versus container production in pines in the American tropics. In: South, D. B. (ed) Proceedings International Symp. Nur. Manag. Prac. for the Southern pines. August 4-9, 1985 Montgomery pp 72-82.

WILSON, P. J. 1986. Containers for tree nurseries in developing countries. Commonwealth Forestry Review 65: 233-240. 